\title{
Characterisation of palygorskite specimens from different geological locales for health hazard evaluation
}

\author{
R P Nolan, A M Langer, G B Herson
}

\begin{abstract}
Palygorskite, a fibrous clay mineral, is being used as a substitute for asbestos in some applications. Nine specimens obtained from different geological locales were studied for mineral purity, elemental composition, fibre size distribution, and surface binding characteristics. The membranolytic activity of each was determined using a human erythrocyte model. The membranolytic behaviour and surface binding characteristics were compared with three chrysotile specimens employed as positive controls. The palygorskite specimens derived from the different geological locales display a range of physicochemical properties. This study shows the importance of selecting several mineral specimens for a health hazard evaluation. The current carcinogenic classification of the mineral may be limited due to the number of specimens used for that particular evaluation.
\end{abstract}

Concern has been raised about the use of palygorskite, a fibrous clay, as an asbestos substitute. ${ }^{1}$ Limited studies have been carried out on select specimens to determine their biological potential. A comprehensive health hazard evaluation, however, should include a determination of the range of the physicochemical properties of the mineral. Although a mineral name, such as palygorskite, specifies a crystalline structure and a limited elemental composition, the principal determinants of activity of a mineral are thought to be its size dimensions, durability, and

Environmental Sciences Laboratory, Brooklyn College, Avenue $H$ and Bedford Avenue, Brooklyn, New York 11210, USA

R P Nolan, A M Langer

Andre Meyer Department of Physics and Nuclear Medicine, Mount Sinai School of Medicine, 1 Gustave L, Levy Place, New York 10029, USA

G B Herson surface properties. These properties may exhibit a large range depending on the mineral's origin. The biologically important properties may be altered further industrially by heating, physical manipulation, or chemical treatment. Regulatory agencies frequently set exposure standards after the evaluation of too limited a number of specimens.

Palygorskite specimens from nine different geological locales were selected for study. Three chrysotile specimens, previously studied using in vitro and in vivo methods were selected for comparison. ${ }^{23}$ The preliminary results of our findings have been presented at a meeting in Quebec in $1988 .{ }^{4}$

Palygorskite is a naturally fibrous clay mineral. The name originates from the Palygorsk Range in the Ural mountains (Novgorod, Soviet Russia) where it was first found in $1861 .{ }^{5}$ Attapulgite, a synonym used for palygorskite, originates from the discovery of the same mineral in Attapulgus, Georgia, USA in $1935 .^{6}$ Its structure consists of two facing amphibole-like chains that are linked by octahedrally coordinated cations. ${ }^{7-9}$ These chains are referred to as ribbons, and impart the fibre with structural elements of both chain and layer silicates.

The two chains contribute four silica tetrahedra each to the unit cell structure (fig 1). Adjacent ribbons share the common oxygen edges of the outermost tetrahedra; the tetrahedra in adjacent ribbons point in opposite directions, and only their bases fall within a common plane. The simple empirical structural chemical formula for palygorskite is:

$$
\left(\left(\mathrm{Si}_{8}\right)^{\mathrm{IV}}\left(\mathrm{Mg}_{5}\right)^{\mathrm{vI}} \mathrm{O}_{20}(\mathrm{OH})_{2}\left(\mathrm{OH}_{2}\right)_{4}\right) 4 \mathrm{H}_{2} \mathrm{O}
$$

Roman numerals indicate structural coordination number and subscript Arabic numerals indicate the number of atoms in the cell. Aluminium substitution may occur in the tetrahedral site, so that $\left(\mathrm{Si}_{8-\mathrm{x}}{ }^{4+}\right.$, $\mathrm{Al}^{3+}{ }_{\mathrm{x}}$ ) results. The octahedral sites created by two facing silica tetrahedra chains generally contain magnesium but other divalent cations, especially $\mathrm{Fe}^{2+}$, may be found as well. Insufficient oxygens (eight which form the apices of the inwardly facing tetrahedra) are present for a complete octahedral configuration of the ribbon, so that six hydroxyl groups 


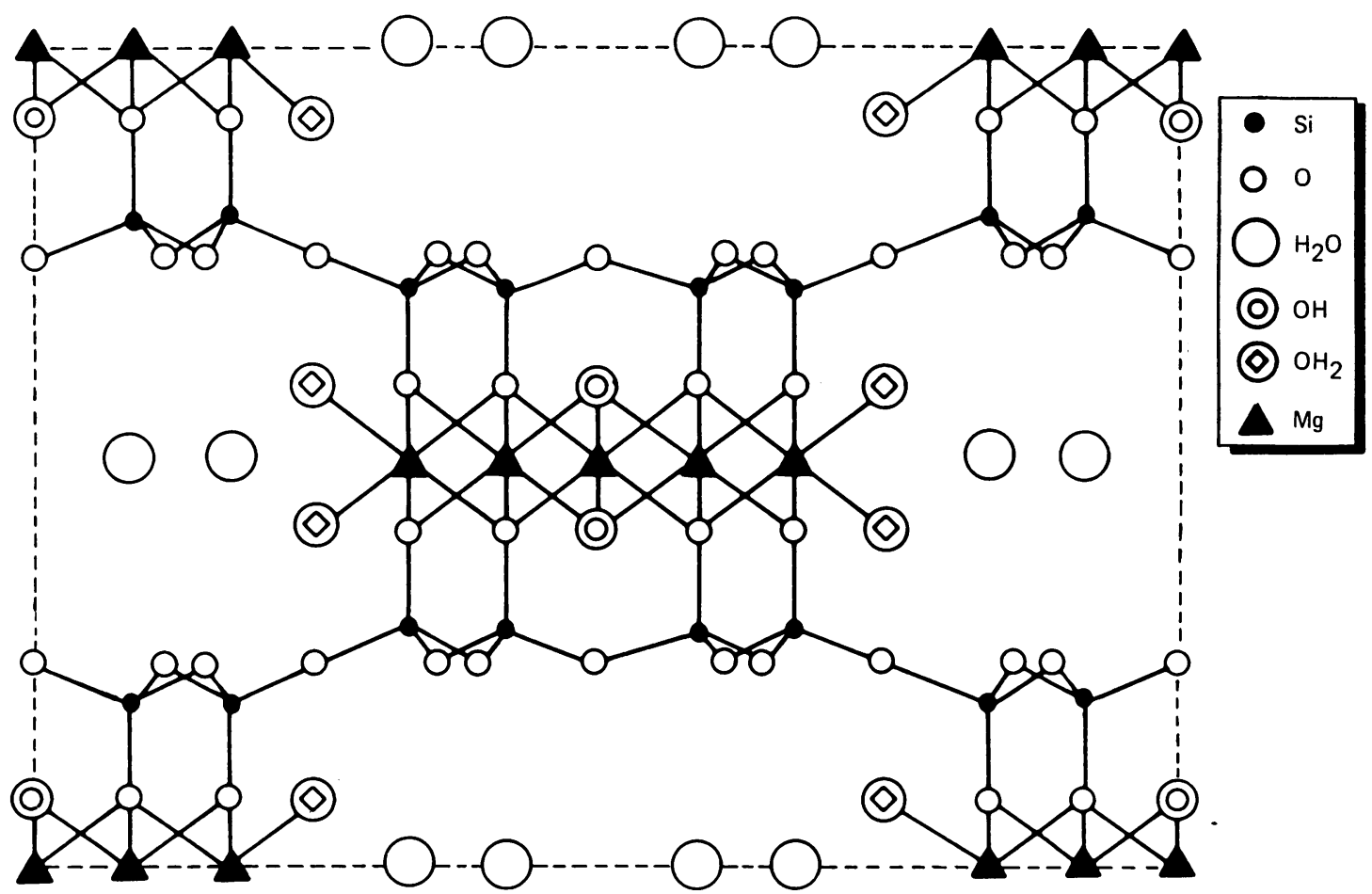

Figure 1 The crystal structure of palygorskite: projected plane normal to the c-axis. (adapted from Brown $G$, ed. $x$ Ray identification and crystal structure of clay minerals, copyright Mineralogical Society, London, 1961:345). The vertical direction is a $\sin \beta$; the horizontal direction is $\mathrm{b}$. The $\mathrm{c}$-axis is normal to this plane.

are required to satisfy the valence requirement (fig 1 ). On average, only four of five octahedral sites are occupied. The octahedral sites are thought to take on some dioctahedral character-that is, substitution with trivalent cations such as $\mathrm{Al}^{3+}$ or $\mathrm{Fe}^{3+}$. Some reports suggest that almost equal amounts of $\mathbf{M g}^{2+}$ and $\mathrm{Al}^{3+}$ may be present. ${ }^{8}$

Additionally, internal channels, roughly $4 \times 5 \AA$, are created by the ribbon configuration. Two water molecules, commonly referred to as zeolitic water, are accommodated within each side channel so that four are contained within each unit cell (fig 1). Further structural transition areas exist in which $\mathrm{Ca}^{2+}$ and other cations may be present. ${ }^{7}$ Potassium is a common minor element in palygorskites and is assumed to be bound at the bases of the silica chain, in the structural channel. The water found in palygorskite has been extensively studied by $x$ ray diffraction, infrared spectroscopy, and by both differential thermal and gravimetric analyses. Natural and deuterated specimens have been examined, as well as specimens subjected to incremental heating. ${ }^{1011}$ Hydroxyl groups, chemically bound water, zeolitic water, and surface adsorbed hygroscopic water molecules have been detected (fig 1).

\section{Materials and methods}

ORIGIN OF PALYGORSKITE AND CHRYSOTILE SPECIMENS The following specimens were obtained from the mineral collection of the American Museum of Natural History (AMNH): palygorskite AMNH No C57079, Brazil; palygorskite AMNH No 27270, Yalu River, Korea; palygorskite AMNH No 24478, Dartmoor, western Australia; palygorskite AMNH No 17887, Nizhi, Novgorod, Soviet Russia; palygorskite AMNH No C57076, Zermatt, Switzerland; palygorskite American Petroleum Institute (API) No 43, Attapulgus, Georgia, USA.

NIOSH A and NIOSH B are industrial palygorskite specimens from the Georgia-Florida deposit and were obtained from Robert Wheeler of the Appalachian Laboratories for Occupational Safety and Health, Morgantown, West Virginia.

Palygorskite, New Melone's Lake, Calaveras, California, USA (this specimen and specimens AMNH No C57079 and No 27270 were opened in a high speed blade mill), UICC Chrysotile A (Zimbabwe), and Chrysotile B (Canada) were obtained from the Pneumoconiosis Research Unit, Penarth, Wales, United Kingdom.

California Chrysotile, RG-144, is a naturally 
occurring, predominantly short fibre chrysotile from New Idria, California. This was obtained in a commercially available form from Union Carbide, New York.

\section{INHIBITORS}

The inhibitors of membranolytic activity were obtained from the following sources: bovine serum albumin (BSA) No A-4378 from Sigma Chemical Company, St Louis, Missouri; 2-(poly-vinylpyridine-N-oxide) (2-PVPNO) from Polyscience, Inc, Warington, Pennsylvania; chondroitin sulphate from R J Schnitzer, Mount Sinai School of Medicine, New York.

\section{HUMAN MEMBRANOLYTIC MODEL}

The ability of each of the mineral specimens to alter the permeability of human erythrocytes was determined quantitatively. The $\mathrm{HC}_{50}$ is the concentration of particulate (given in $\mu \mathrm{g} / \mathrm{ml}$ ) required to lyse $50 \%$ of the erythrocytes in a suspension containing $1.8 \times 10^{8}$ cells $/ \mathrm{ml}$ (see Nolan et al $^{12}$ for details).

\section{Results}

\section{$X$ RAY DIFFRACTION ANALYSIS OF SPECIMENS}

The specimens were examined by continuous scan $x$ ray diffraction between $3^{\circ}$ and $65^{\circ} 2 \theta$. Roughly $100 \mathrm{mg}$ of powders were packed into specimen holders and subjected to the scan conditions given by Nolan et al. ${ }^{12}$ The resulting patterns were compared with the file data provided by the joint committee on standard power diffraction for palygorskite based on specimens from Sapillo, New Mexico; Glasgow, Virginia; Metaline, Washington; and the original data by Bradley. ${ }^{13}$ The data for the first two reference patterns may be confounded by the presence of quartz.

Each palygorskite specimen produced a pattern consistent for that mineral. Every specimen also contained some detectable crystalline mineral impurities. Importantly, all contained detectable amounts of quartz. The Australian, NIOSH A and B, Brazilian, and Russian specimens contained substantial amounts ranging from some $5 \%$ to about $50 \%$ of the mass of the specimen. The Attapulgus, Georgia specimen contained sepiolite. The carbonate minerals, calcite and dolomite, and other clays were also frequently found (table 1).

Except for the clays, the mineral impurities tended to form well defined sharp reflections often appearing as peaks emerging from a line broadened palygorskite pattern. For example, the quartz $4.26 \AA$ reflection (101) emerged as a well defined peak from two broad palygorskite reflections, $4 \cdot 47 \AA(040)$ and $4 \cdot 13 \AA$ (310), which occur as a single line broadened doublet over the $19^{\circ}-23^{\circ} 2 \theta$ region of the pattern.

The peaks attributable to palygorskite in the continuous scan $x$ ray tracing for the Korean specimen gave relatively sharp, intense, well defined reflections compared with the tracings of many other attapulgite specimens (which were extremely line broadened). Transmission electron microscopical (TEM) analysis of this specimen indicated the presence of short lath-like fibrils that resembled short amphibole fibres (see fig 5).

Table 1 Optical and $x$ ray diffraction character of palygorskite specimens

\begin{tabular}{|c|c|c|c|c|}
\hline \multirow[b]{2}{*}{ Specimen } & \multirow[b]{2}{*}{ Fibre character } & \multirow{2}{*}{$\begin{array}{l}\text { Continuous scan } x \text { ray } \\
\text { pattern }\end{array}$} & \multicolumn{2}{|c|}{ Other minerals observed $†$} \\
\hline & & & Optical & $X R D$ \\
\hline $\begin{array}{l}\text { Brazil } \\
\text { Korea } \\
\text { Switzerland } \\
\text { Soviet Russia } \\
\text { California } \\
\text { Georgia } \\
\text { Australia } \\
\text { NIOSH A } \\
\text { NIOSH B }\end{array}$ & $\begin{array}{l}\text { Long, separate } \\
\text { Short, matted } \\
\text { Short, matted } \\
\text { Short, matted } \\
\text { Short, matted } \\
\text { Unresolved } \\
\text { Unresolved } \\
\text { Unresolved } \\
\text { Unresolved }\end{array}$ & $\begin{array}{l}\text { Well defined, sharp } \\
\text { Good, well defined } \\
\text { Good, well defined } \\
\text { Broadened } \\
\text { Broadened } \\
\text { Broadened } \\
\text { Broadened } \\
\text { Broaderted } \\
\text { Broadened }\end{array}$ & $\begin{array}{l}\text { Q, L } \\
\mathbf{Q}, \mathbf{A} \\
\mathbf{A}, \mathbf{O}, \mathrm{CO}_{3} \\
\mathbf{Q} \\
\mathbf{Q}, \mathbf{A}, \mathbf{O} \\
\mathbf{Q}, \mathbf{F}, \mathbf{O} \\
\mathbf{Q}, \mathbf{F}, \mathbf{O}, \mathbf{A} \\
\mathbf{Q}, \mathrm{CO}_{3}, \mathbf{A} \\
\mathbf{Q}, \mathrm{CO}_{35} \mathbf{A}\end{array}$ & $\begin{array}{l}Q(25-50 \%)+ \\
Q(\text { trace }), O \\
Q(\text { trace }), \mathrm{CO}_{3}, 2 \mathrm{C} \\
\mathbf{Q}(5-10 \%) \\
Q(\text { trace }), 2 \mathrm{C} \\
\mathrm{S}, \mathrm{C}, \mathrm{Q}(1-2 \%) \\
\mathrm{Q}(-50 \%), \mathrm{C} \\
\mathrm{Q}(2-5 \%), \mathrm{CO}_{3}, 2 \mathrm{C} \\
\mathrm{Q}(2-5 \%), 2 \mathrm{CO}_{3}, 2 \mathrm{C}, \mathrm{F}\end{array}$ \\
\hline
\end{tabular}

$\star_{x}$ Ray diffraction system, analytical geometry, and settings as outlined in Nolan et al. ${ }^{22}$ The patterns described as good, well defined, or sharp produce characteristic reflections over a range of $0^{\circ} \cdot 5-1.0^{\circ} 2 \theta$ when scanned at $1^{\circ} 2 \theta /$ minute. High quality crystalline quartz, for example, Min-U-Sil 15, produces such a pattern. On the other hand, patterns described as broadened produce reflections over a range of $2^{\circ}-7^{\circ} 2 \theta$ when scanned at $1^{\circ} 2 \theta /$ minute. Chrysotile asbestos produces such a pattern. As with chrysotile, several $d-s p a c i n g s$ in close proximity may be seen as shoukers emerging from a single, broad, continuum above the baseline.

+Other minerals observed: $\mathrm{Q}$ (quartz); $\mathrm{F}$ (feldspar); $\mathrm{S}$ (sepiolite); $\mathrm{CO}_{3}$ (carbonate mineral); $\mathrm{C}$ (clay mineral other than palygorskite or sepiolite); L (iron or limonite stain); $\mathbf{A}$ (altered particle, either feldspar or ferromagnesium mineral); $O$ (other mineral particle, crystalline, no identification made). Note notation $2 \mathrm{C}$ (montmoriflonite, chlorite, vermiculite, or other clay, for example, illite, translates into more than one clay); $2 \mathrm{CO}_{3}$ (denotes presence of both calcite and dolomite).

$+\%$ By weight of $Q$ in parentheses. 


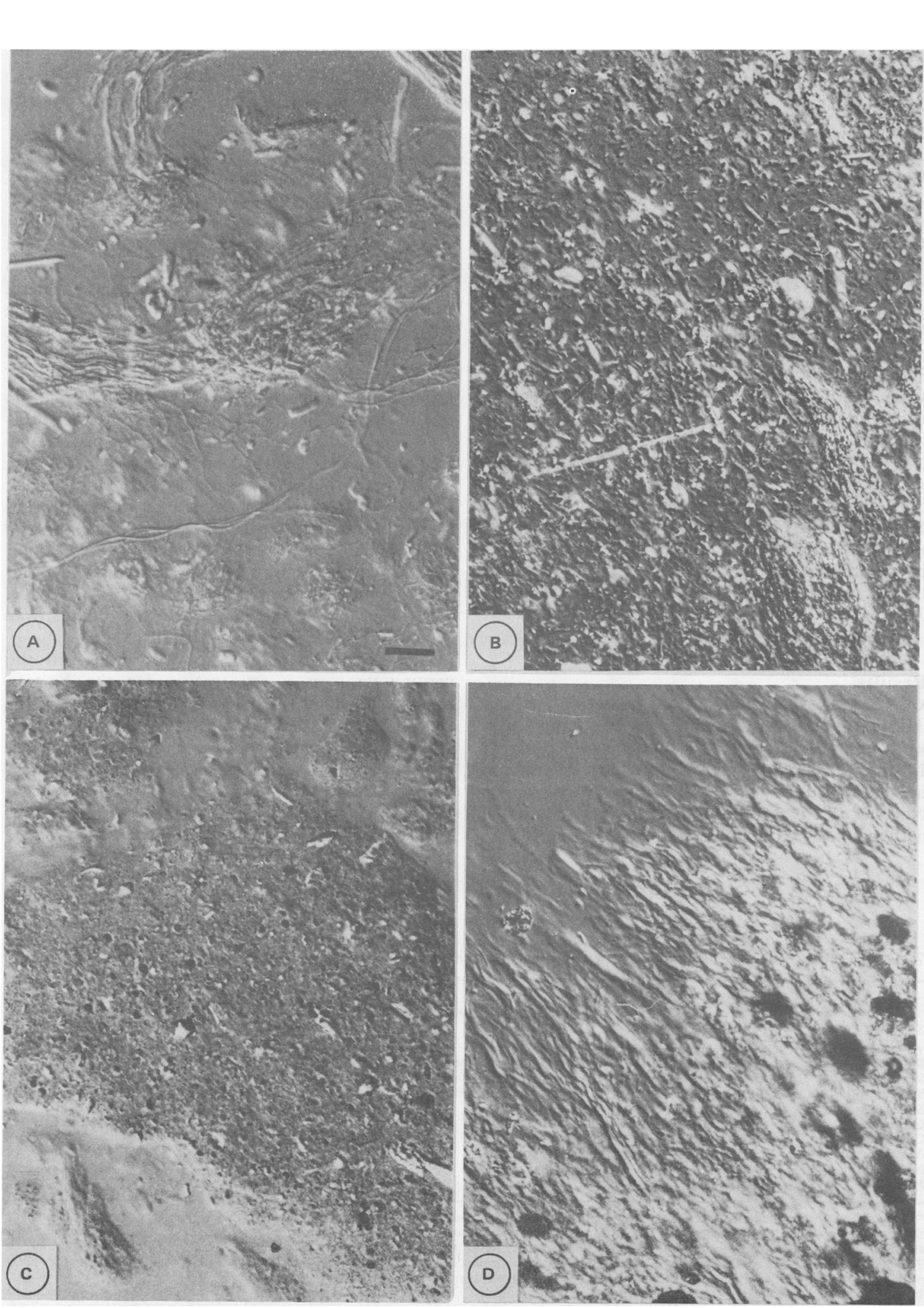

Figure 2 Photomicrographs obtained by interference light microscopy of $(A)$ chrysotile, Canadian UICC; $(B)$ chrysotile, California; (C) palygorskite, New Melone's Lake, California; and (D) palygorskite, Zermatt, Switzerland. Bar width equals $50 \mu \mathrm{m}$. 
Table 2 Elemental ratios (SD) of palygorskite obtained from different localities

\begin{tabular}{|c|c|c|c|c|c|c|c|c|c|c|c|}
\hline \multirow[b]{2}{*}{$\begin{array}{l}\text { Specimen } \\
\text { Brazil } \\
\text { Korea } \\
\text { Australia } \\
\text { Soviet Russia } \\
\text { Switzerland } \\
\text { Georgia } \\
\text { NIOSH A } \\
\text { NIOSH B } \\
\text { California }\end{array}$} & $\begin{array}{l}\begin{array}{l}\text { No of } \\
\text { samples }\end{array} \\
\begin{array}{r}9 \\
10\end{array}\end{array}$ & \multicolumn{2}{|c|}{$M g: S i$} & \multicolumn{2}{|c|}{$F e: S i$} & \multicolumn{2}{|c|}{$A l: S i$} & \multicolumn{2}{|l|}{$K: S i$} & \multicolumn{2}{|c|}{$C a: S i$} \\
\hline & $\begin{array}{r}9 \\
10 \\
11 \\
13 \\
11 \\
11 \\
30 \\
14 \\
15\end{array}$ & $\begin{array}{l}0.22 \\
0.21 \\
0.18 \\
0.22 \\
0.16 \\
0.22 \\
0.17 \\
0.21 \\
0.15\end{array}$ & $\begin{array}{l}(0.02) \\
(0.03) \\
(0.02) \\
(0.03) \\
(0.02) \\
(0.02) \\
(0.02) \\
(0.02) \\
(0.03)\end{array}$ & $\begin{array}{l}0.07 \\
0.05 \\
0.07 \\
0.06 \\
0.03 \\
0.09 \\
0.06 \\
0.09 \\
0.09\end{array}$ & $\begin{array}{l}(0.01) \\
(0.02) \\
(0.03) \\
(0.02) \\
(0.01) \\
(0.01) \\
(0.02) \\
(0.02) \\
(0.01)\end{array}$ & $\begin{array}{l}0 \cdot 30 \\
0 \cdot 22 \\
0.24 \\
0 \cdot 26 \\
0 \cdot 22 \\
0 \cdot 21 \\
0 \cdot 17 \\
0.20 \\
0 \cdot 12\end{array}$ & $\begin{array}{l}(0.02) \\
(0.02) \\
(0.02) \\
(0.02) \\
(0.02) \\
(0.01) \\
(0.03) \\
(0.03) \\
(0.02)\end{array}$ & $\begin{array}{l}0.07 \\
0.06 \\
0.05 \\
0.08 \\
0.05 \\
0.06 \\
0.04 \\
0.06 \\
0.02\end{array}$ & $\begin{array}{l}(0.01) \\
(0.03) \\
(0.01) \\
(0.03) \\
(0.01) \\
(0.02) \\
(0.02) \\
(0.02) \\
(0.01)\end{array}$ & $\begin{array}{l}0.07 \\
0.08 \\
0.06 \\
0.07 \\
0.04 \\
0.06 \\
0.03 \\
0.06 \\
0.03\end{array}$ & $\begin{array}{l}(0.01) \\
(0.04) \\
(0.02) \\
(0.03) \\
(0.01) \\
(0.02) \\
(0.02) \\
(0.02) \\
(0.03)\end{array}$ \\
\hline
\end{tabular}

EXAMINATION OF PALYGORSKITE SPECIMENS BY POLARISED LIGHT MICROSCOPY

Each specimen was examined by polarised light microscopy using the full range of optical magnifications and liquids of different refractive indices. Fibres in the palygorskite specimens, known to be present from examination by TEM, were not always observable by light microscopy. ${ }^{4}$ Nondescript clumps and aggregates were often seen (table 1 and fig 2). By contrast, the chrysotile specimens all appeared fibrous by optical microscopy (fig 2). Those specimens of palygorskite that appeared non-fibrous by optical microscopy invariably produced line broadened $x$ ray diffraction tracings. The specimens with larger optically visible fibres yield much sharper diffraction patterns with far less evidence of line broadening. It may be concluded that the detection of fibres by light microscopy reflects crystal texture-that is, a progressive increase in three dimensional periodicity.

\section{CHEMISTRY OF PALYGORSKITE SPECIMENS}

Chemical data were obtained on 124 fibrils or fibre bundles within the nine palygorskite specimens by means of energy dispersive $x$ ray spectrometry (table
2). $x$ Ray counts were accumulated for a fixed time (100 seconds) over a specific portion of the energy spectrum (0 to $10240 \mathrm{eV}$ ). $x$ Ray patterns were accumulated in channels of $10 \mathrm{eV}$ widths (1024 channels). Six elements were targeted within specific regions of interest that centered on the respective $K_{\alpha}$ peak-namely, $\mathrm{Mg}, 1 \cdot 170$ to $1.330 \mathrm{KeV}$; Al, 1.400 to $1.540 \mathrm{KeV}$; Si, 1.660 to $1.820 \mathrm{KeV}$; K, $3.230 \mathrm{ti}$ $3.410 \mathrm{KeV}$; Ca, 3.610 to $3.790 \mathrm{KeV}$; and $\mathrm{Fe}, 6.310$ to $6.500 \mathrm{KeV}$. The accumulated spectra were smoothed by signal averaging relative to adjacent juxtaposed channels and recalibrated around peak centres (around $\mathrm{K}_{\alpha}$ ). Background counts were subtracted from gross counts, which were obtained as total counts of the full width at half maximum of the peak. These values tend to eliminate interfering counts from adjacent peak tails. It was noted that the $K_{\alpha}$ peak for $\mathrm{Si}$ contributes negligibly to the $\mathrm{Al}$ region of interest. These values are shown in table 2. The numbers, calculated as a ratio of $\mathrm{Si}$, represent a first order approximation of the atomic weight per cent ratio of the constituent element to $\mathrm{Si}$ :

$$
\frac{I_{x}}{I_{s i}} \approx \frac{\operatorname{Conc}(X)}{\operatorname{Conc}(S i)}
$$

Table 3 Fibre lengths of palygorskite and chrysotile specimens determined by sizing from TEM photographs printed at a final enlargement of $5000 \times$

\begin{tabular}{|c|c|c|c|c|c|}
\hline \multirow[b]{2}{*}{ Specimen location } & \multirow[b]{2}{*}{ No of fibres sized } & \multicolumn{4}{|c|}{ Fibre length $(\mu \mathrm{m})^{\star}$} \\
\hline & & $<1 \cdot 0$ & $1 \cdot 1-5 \cdot 0$ & $5 \cdot 1-10 \cdot 0$ & $>10 \cdot 0$ \\
\hline \multicolumn{6}{|c|}{ Palygorskite specimens (\%) } \\
\hline Brazil & 1687 & $71 \cdot 5$ & 26.3 & $1 \cdot 7$ & $0 \cdot 5$ \\
\hline Korea & 1023 & $92 \cdot 7$ & $7 \cdot 1$ & - & - \\
\hline Australia & 797 & $90 \cdot 2$ & $9 \cdot 3$ & $0 \cdot 3$ & $0 \cdot 3$ \\
\hline Soviet Russia & 1874 & $78 \cdot 0$ & $21 \cdot 3$ & $0 \cdot 7$ & $0 \cdot 2$ \\
\hline Switzerland & 3710 & $75 \cdot 1$ & $22 \cdot 4$ & $2 \cdot 0$ & 0.6 \\
\hline Georgia & 2500 & $91 \cdot 1$ & $8 \cdot 7$ & $0 \cdot 1$ & $0 \cdot 1$ \\
\hline NIOS̆H A & 1315 & $83 \cdot 4$ & $16 \cdot 6$ & - & - \\
\hline NIOSH B & 2500 & $83 \cdot 1$ & $16 \cdot 8$ & - & - \\
\hline California & 1995 & $59 \cdot 4$ & $37 \cdot 5$ & $2 \cdot 6$ & 0.6 \\
\hline \multicolumn{6}{|c|}{ Chrysotile specimens (\%) } \\
\hline California & 2939 & $77 \cdot 2$ & $20 \cdot 5$ & $1 \cdot 8$ & 0.5 \\
\hline Canada & 2903. & $84 \cdot 9$ & $13 \cdot 6$ & 0.6 & 0.4 \\
\hline Zimbabwe & 3523 & $88 \cdot 8$ & $10 \cdot 6$ & 0.4 & 0.2 \\
\hline
\end{tabular}

*All fibres $<0.15 \mu \mathrm{m}$ in diameter. 

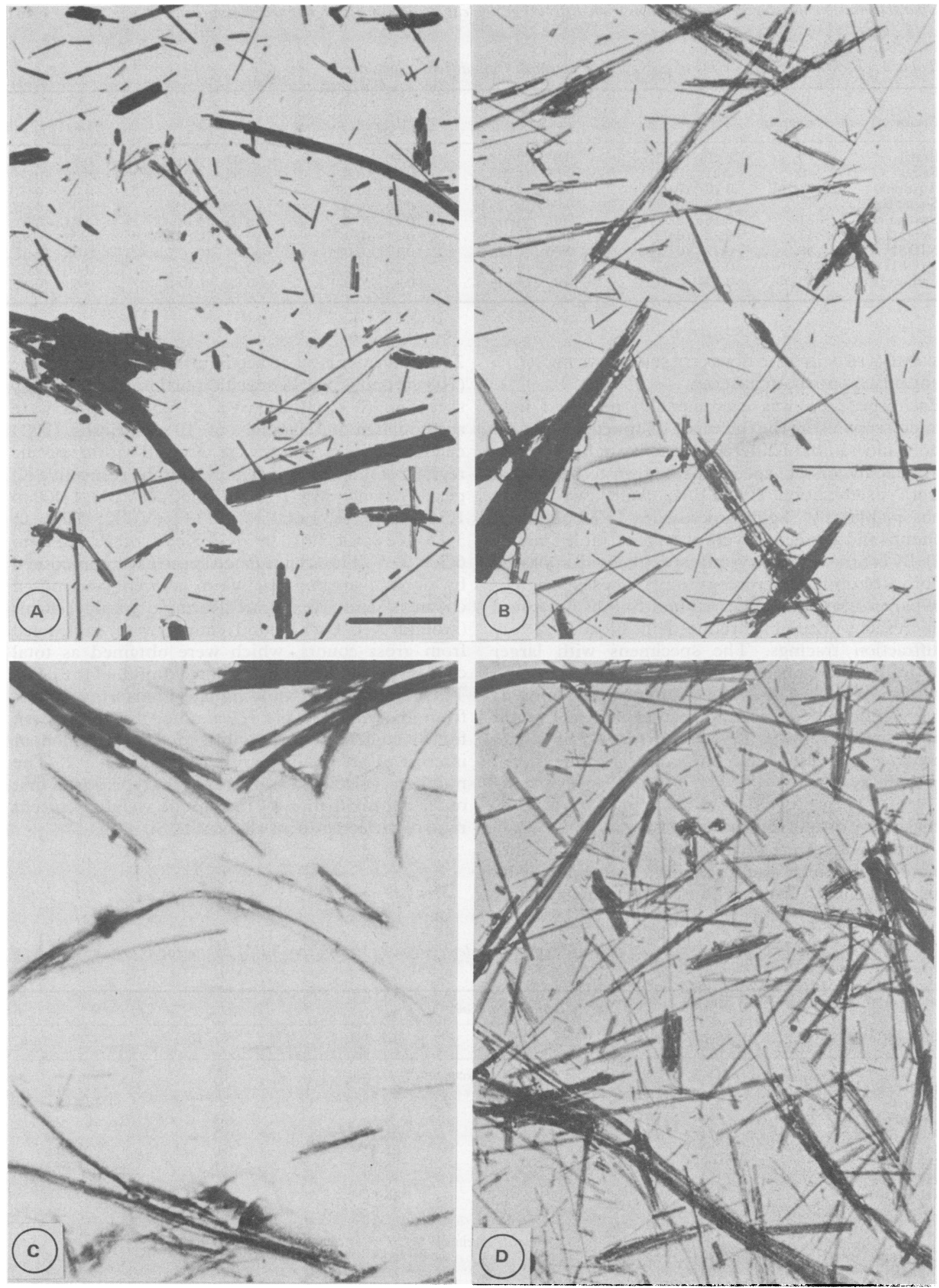

Figure 3 Transmission electron micrograph of $(A)$ chrysotile, Canadian UICC; (B) chrysotile, California;

(C) palygorskite, New Melone's Lake, California; and (D) palygorskite, Zermatt, Switzerland. Bar represents $2 \mu m$ length. All figures are at same magnification. Morphology, fibril diameter, and state of aggregation of these specimens are virtually identical. 

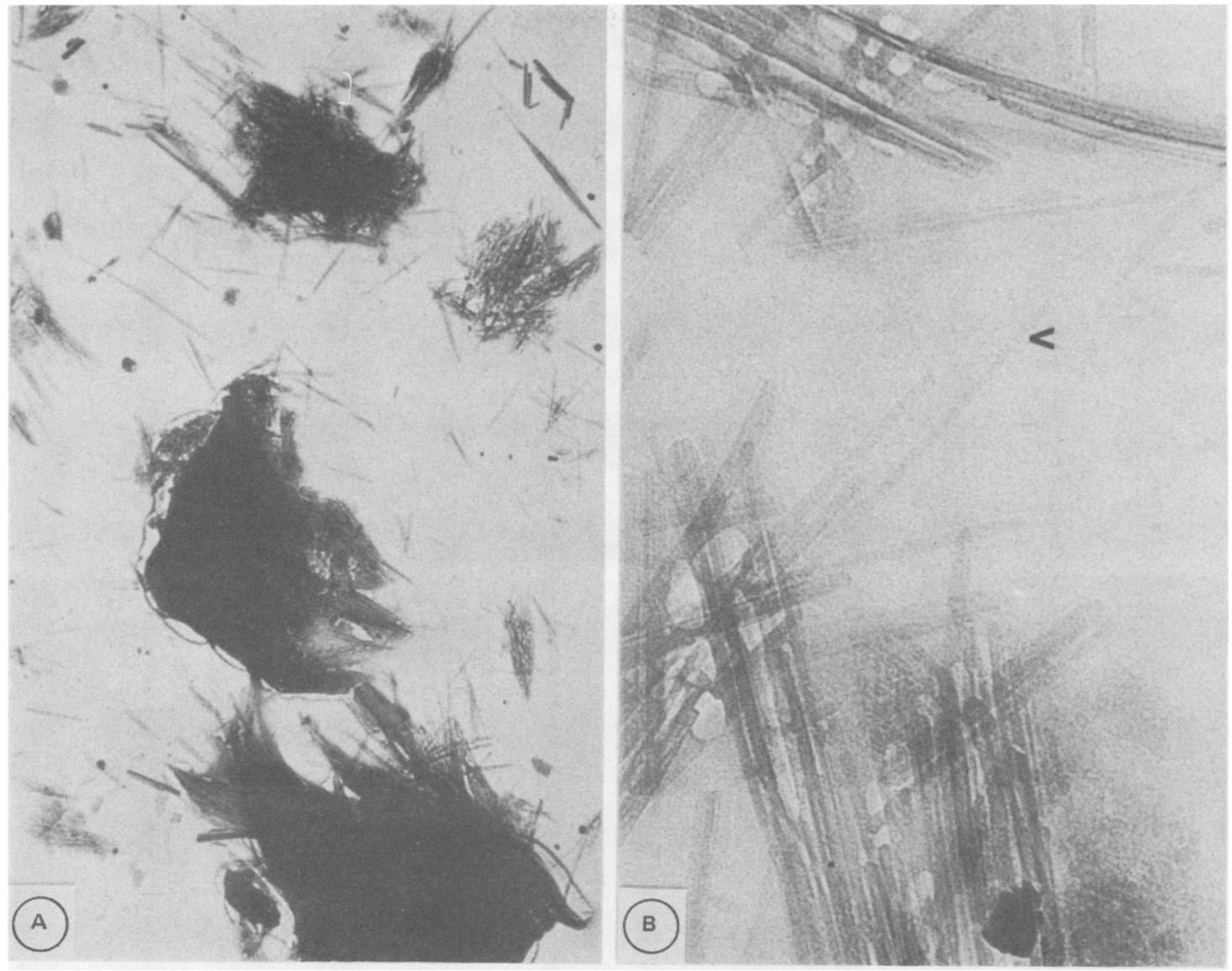

Figure 4 Resolution of fibrils of palygorskite in NIOSH specimen B by transmission electron microscopy. (A) shows aggregate clumps viewed at low magnification. Central clump is about $3.5 \mu \mathrm{m}$ across (horizontal axis). (B) shows individual fibrils at high magnification. Arrowhead points to a fibril with a diameter of about $0.01 \mu m(100 \AA)$.

where $\mathrm{I}_{\mathrm{x}}$ equals intensity (corrected $x$ ray counts in the region of interest of element $\mathrm{X}$ ) divided by the $\mathrm{Si}$ intensity $\left(\mathrm{I}_{\mathrm{Si}}\right)$. This ratio approximates to the atomic weight concentration ratio of these elements.

The essential chemistry of palygorskite is that of an aluminium silicate with $\mathrm{Mg}$ as its principal cation. Magnesium always dominates over Fe. Potassium and $\mathrm{Ca}$ are also present and appear to increase in concentration together, suggesting a common origin. There does not appear to be any correlation between fibre size and elemental composition (compare data in tables 2 and 3 ) or between elemental composition and membrane activity (compare data in tables 2 and 4 ).

\section{DETERMINATION OF FIBRE SIZE DISTRIBUTIONS BY}

\section{TRANSMISSION ELECTRON MICROSCOPY}

The size distributions were determined from photographs taken at $2000 \times$ direct magnification and photographically enlarged to $5000 \times$. Overlapping photographs were taken so that photomontages could be made to allow sizing of long fibres (for details, see Nolan et al. ${ }^{4}$ ) Fibres were sized into four different groups: $\leqslant 1 \mu \mathrm{m}, 1 \cdot 1-5.0 \mu \mathrm{m}, 5 \cdot 1-10.0 \mu \mathrm{m}$, and $>10 \mu \mathrm{m}$. All sized fibres had an aspect ratio of $3: 1$ or greater and a diameter of $<0 \cdot 15 \mu \mathrm{m}$ (table 3; figs 3, 4, and 5).

A comparison of the size distributions of the respirable fractions of palygorskite with similar fractions of chrysotile shows them to be very similar. Both mineral types are constituted of short fibres.

\section{MEMBRANOLYTIC ACTIVITY AND THE EFFECT OF} INHIBITORS

The membranolytic activity of the palygorskite specimens varied from inactive for the Korean specimen to highly active ( 51 (SD 10$) \mu \mathrm{g} / \mathrm{ml}$ ) for the California specimen. Among the active specimens a factor of almost 15-fold separated the least and most 

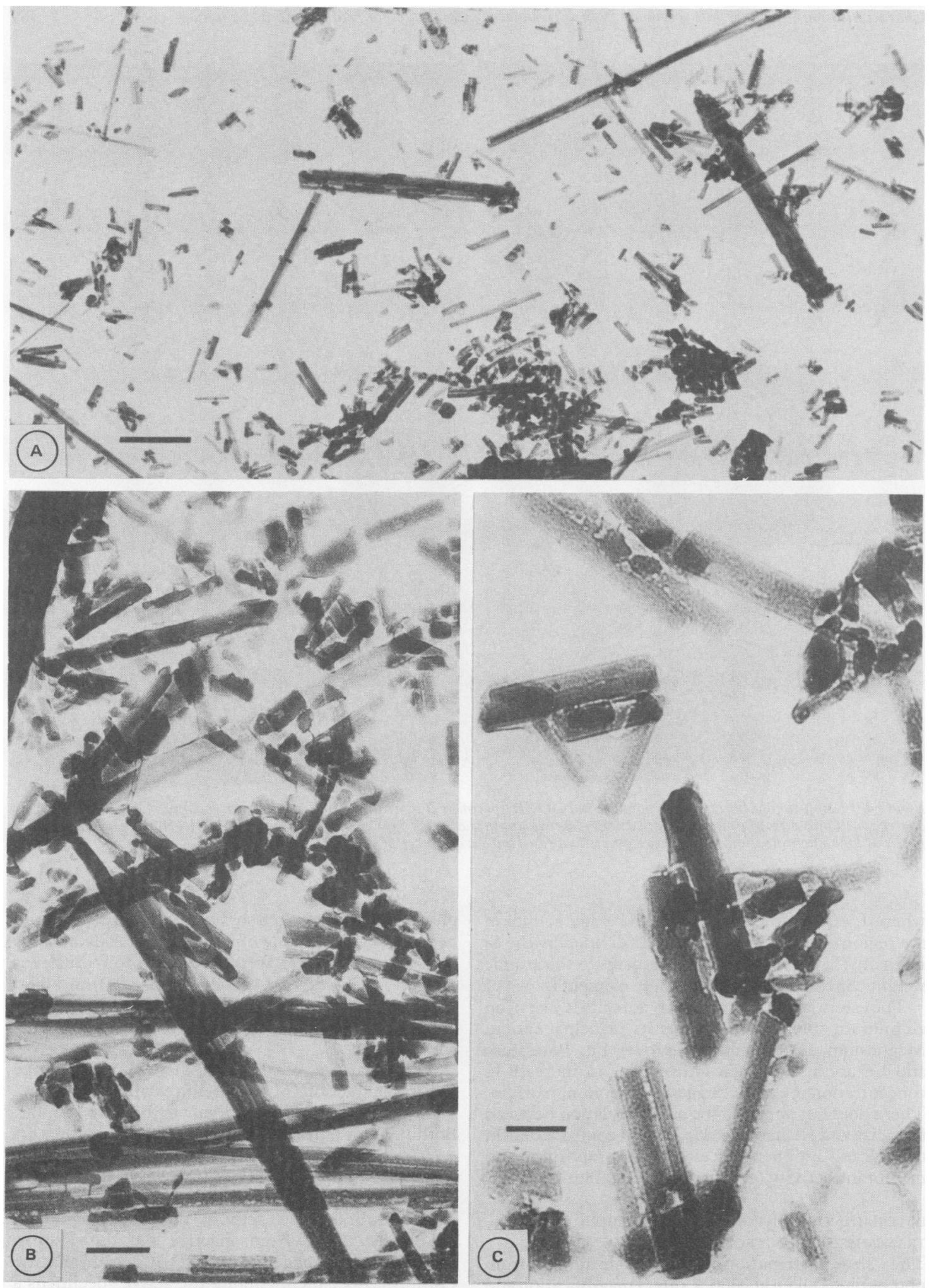

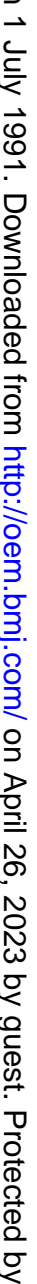

Figure 5 Transmission electron micrograph of palygorskite, Korea, at three different magnifications. $(A)$ bar represents $1.0 \mu \mathrm{m} ;(B)$ bar represents $0.25 \mu \mathrm{m} ;(C)$ bar represents $0.12 \mu \mathrm{m}$. The fibrils of this palygorskite morphologically resemble short amphibole fibrils rather than chrysotile. 
Table 4 Membranolytic activity, quartz content determined by continuous scan $x$ ray diffraction, and visibility of fibres by light microscopy

\begin{tabular}{|c|c|c|c|}
\hline Specimen location & $H C_{s o}^{\star}(\mu g)$ & Quartz content ( $\%$ ) & Fibre resolution by optical microscopy \\
\hline \multicolumn{4}{|c|}{ Palygorskite specimens } \\
\hline Brazil & $400 \quad(101)$ & $25-50$ & Fibrous \\
\hline Korea & Inactive & Trace & Fibrous \\
\hline Australia & $746 \quad(159)$ & $\sim 50$ & Non-fibrous \\
\hline Soviet Russia & $211 \quad(168)$ & $5-10$ & Fibrous \\
\hline Switzerland & $369 \quad(75)$ & Trace & Fibrous \\
\hline Georgia & $76 \quad(35)$ & $1-2$ & Non-fibrous \\
\hline NIOSH A & $83 \quad(26)$ & $2-5$ & Non-fibrous \\
\hline NIOSH B & $109 \quad(12)$ & $2-5$ & Non-fibrous \\
\hline California & $51 \quad(10)$ & Trace & Fibrous \\
\hline \multicolumn{4}{|c|}{ Chrysotile specimens } \\
\hline California & $41 \quad(3)$ & $\mathrm{ND}_{+}^{+}$ & Fibrous \\
\hline Canada & (19) & $\mathrm{ND}^{+}$ & Fibrous \\
\hline Zimbabwe & (3) & ND & Fibrous \\
\hline
\end{tabular}

*Concentration of mineral required to lyse $50 \%$ of $1.8 \times 10^{8}$ erythrocytes $/ \mathrm{ml}$.

†nactive $=\geqslant 1500 \mu \mathrm{g} / \mathrm{ml}$.

$\ddagger$ ND $=$ Not detected.

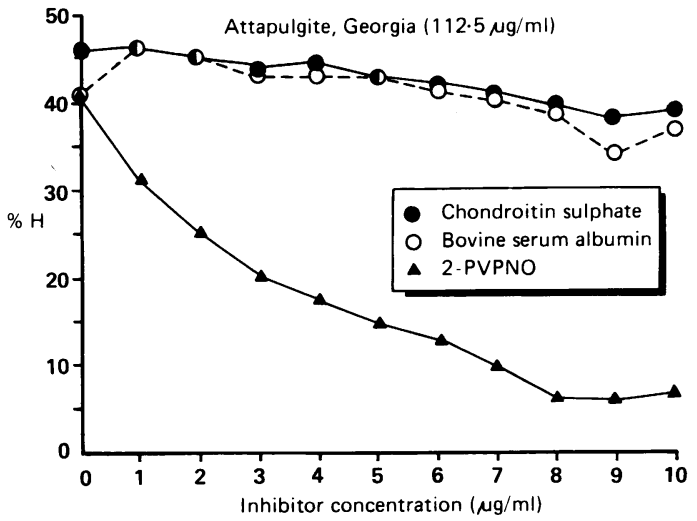

Figure 6 Effect of chondroitin sulphate, $B S A$, and 2-PVPNO on the membranolytic activity of palygorskite from Attapulgus, Georgia. The surface properties are similar to quartz rather than chrysotile.

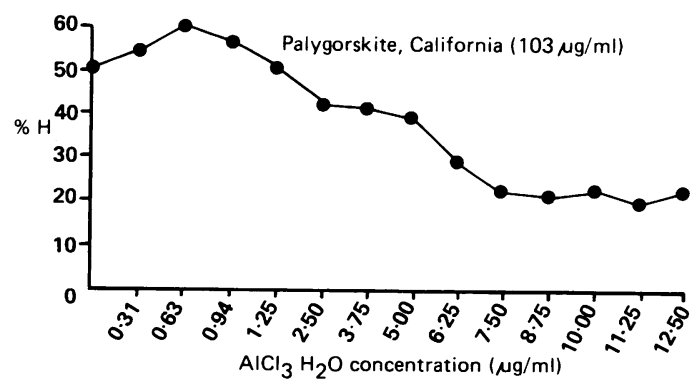

Figure 7 Effect of $\mathrm{Al}^{3+}$ (as $\mathrm{AlCl}_{3} \mathrm{H}_{2} \mathrm{O}$ ) on the membranolytic activity of palygorskite from California. The palygorskite surface properties are consistent with quartz. active. The three chrysotile specimens had an average $\mathrm{HC}_{50}$ of 60 (SD 21) $\mu \mathrm{g} / \mathrm{ml}$ that was comparable with the most active palygorskites (table 4 ). Among the chrysotile specimens a twofold difference existed between the least and the most active.

The inhibitory properties of three polymers, chondroitin sulphate, BSA, and 2-PVPNO on palygorskite membranolytic activity were determined. Over the concentration range studied, only 2-PVPNO exhibited any inhibitory activity (fig 6). Although not effective for palygorskite, both chondroitin sulphate and BSA would effectively inhibit lysis by chrysotile under these conditions. All of the active palygorskite specimens were inhibited by 2-PVPNO. A concentration of $<10 \mu \mathrm{g} / \mathrm{ml}$ of $\mathrm{Al}^{3+}$ could effectively inhibit $60 \%$ of the lysis caused by the most active palygorskite (fig 7).

\section{Discussion and conclusions}

The ratio of different elements present to $\mathrm{Si}$ and the continuous scan $x$ ray diffraction characteristics of the nine specimens were consistent with the mineral palygorskite. The physicochemical properties of the specimens that impart membranolytic activity (fibre size distribution, surface properties, and mineral purity) varied significantly depending on the geological origin.

The dose is determined by the size distribution, particularly the diameter (length differences of thin fibres contribute very little to the surface area), and density. The diameters of the active palygorskite specimens are similar to the three chrysotile specimens and the density of palygorskite is $5 \%$ less than chrysotile. The similarity between the density and fibre diameters indicates that the mass of fibre $/ \mathrm{ml}$ required to lyse half of the $1.8 \times 10^{8}$ erythrocytes $/ \mathrm{ml}$, the $\mathrm{HC}_{50}$, should be similar. The average $\mathrm{HC}_{50}$ of the 
three most active palygorskites and the three chrysotile specimens were 70 (SD 17) $\mu \mathrm{g} / \mathrm{ml}$ and 61 (SD 21) $\mu \mathrm{g} / \mathrm{ml}$ respectively. The third most fibrous specimen from Switzerland was fivefold less active, and this is most likely related to the specimen's surface properties.

The relation between surface properties and fibre size is best understood in the haemolysis assay, of all in vitro methods. ${ }^{14-19}$ Although the activities of the chrysotile and palygorskite can be similar, both the surface properties and the mechanisms of erythrocyte lysis are distinctly different. Palygorskite has a net negative charge whereas chrysotile is positively charged. Haemolysis of chrysotile is antagonised by BSA, a net negatively charged protein, and anionic polymers such as chondroitin sulphate. By contrast, palygorskite lysis was inhibited by 2-PVPNO and $\mathrm{Al}^{3+}$, which are the antagonists of quartz and amphibole lysis. ${ }^{12} 1516$ Inhibition of palygorskite lysis by BSA and dipalmitoyl phosphatidyl choline (DPPC) has been reported. The concentration of BSA $(20 \%$ and $80 \%$ of the palygorskite mass) and DPPC ( $50 \%$ and $100 \%$ of the mass of palygorskite) was much higher than used in the experiments reported here. ${ }^{20}$

The Californian palygorskite, which contains the largest percentage of long fibre, was the most membranolytic per unit mass whereas the Korean specimen was inactive and contained the highest percentage of short fibres (tables 3 and 4). The short Korean fibre contains enough surface area, based on its similarity in size distribution, to produce measurable haemolysis at $1500 \mu \mathrm{g} / \mathrm{ml}^{21}$ The inactivity of the Korean specimen is most likely related to surface properties and not fibre size.

All of the palygorskite specimens examined contained detectable amounts of quartz as shown by continuous scan $x$ ray diffraction. The presence of quartz is worth noting because of a recent spate of reports indicating it to be carcinogenic in certain animal bioassays (see Saffiotti and Stinson ${ }^{22}$ for a review). The two specimens containing the highest concentration of quartz, Brazil and Australia, were the least active of all the membranolytic specimens (table 4). Quartz on a mass basis is less membranolytically active than palygorskite. ${ }^{43}$ The variation in the $\mathrm{HC}_{50}$ of the other palygorskite specimens could not be clearly related to a mineral impurity.

Morphology and durability are most often considered responsible for imparting a population of fibres with mesotheliomagenic activity. ${ }^{24-26}$ The evidence for this depends mainly on injection and implantation studies because very few mesotheliomas have ever been experimentally induced by inhalation. ${ }^{27}$ These experiments indicate that fibres $\geqslant 8 \mu \mathrm{m}$ in length and $\leqslant 0.25 \mu \mathrm{m}$ in diameter often referred to as Stanton fibres are the most potent for inducing mesothelioma. Theoretically the greatest surface area per unit mass is produced by the fibre morphology. The surface area increases as the square of the diameter so that the total surface area is strongly dependent on diameter. ${ }^{21}$ This is particularly significant for palygorskite, which tends to form fibres with $0.01 \mu \mathrm{m}$ diameters. An examination of the experience in Paakila where asbestiform anthophyllite produced no human mesothelioma indicates the true upper diameter limit, maybe $0.1 \mu \mathrm{m} .^{28}$ The potential to maximise the surface area per unit mass combined with the difficulty of clearing fibres from the lung may explain the correlation between morphology and induction of mesothelioma. Equally of interest is the diversity of fibre types which can induce tumours by implantation or injection, often cited as evidence that fibre surface has little importance in carcinogenesis.

The measurements of fibre length for all the palygorskite specimens indicate that about $1.3 \%$ of the fibres are $>5 \mu \mathrm{m}$ in length and about $0.3 \%$ are $>10 \mu \mathrm{m}$ (table 3 ). The three chrysotile specimens contained about $1 \cdot 3 \%$ of fibres $>5 \mu$ m and $0.4 \%>10$ $\mu \mathrm{m}$. The three chrysotile specimens have fibre lengths which fall between the shortest and the longest palygorskite specimens (figs 8 and 9). Absorption granules contaminated with palygorskite or sepiolite have been evaluated using long fibres as an indicator of health hazard potential. ${ }^{29} 30$

Fibre specimens containing a similar number of Stanton fibres can have the complete range of activities. Stanton and co-workers reported a $100 \%$ tumour probability from the surgical implantation on a pledget, of two tremolite specimens, whereas a talc specimen having twice the number of Stanton fibres as either tremolite specimen produced no tumours. Even with the very high doses used in these experiments, made even higher by pledget restricting the dose to a smaller area of the lung, a similar number of Stanton fibres produced completely different results. ${ }^{24}$ The fibres in the talc specimen have been identified as a fibrous form of talc called agalite (A G Wiley, personal communication). Quartz, a non-fibrous mineral, has also induced mesotheliomas by injection. ${ }^{31}$ Mesotheliomas have also been produced in rats by the intraperitoneal injection of ferric saccharate in which no fibre is present at all. The catalysis of Fenton's reaction by the iron is thought to generate the transforming factor. ${ }^{32}$ Iron was detected in all the palygorskite specimens examined.

Inhalation studies have shown that two different mineral fibres having similar size distributions need not present a comparable risk of mesothelioma by inhalation. A comparison of crocidolite and the fibrous zeolite mineral erionite by inhalation produced $0 \%$ and $100 \%$ mesothelioma respectively. ${ }^{27}$ The report stated that the fibres found in both dust clouds were of "similar size range." Even a non- 


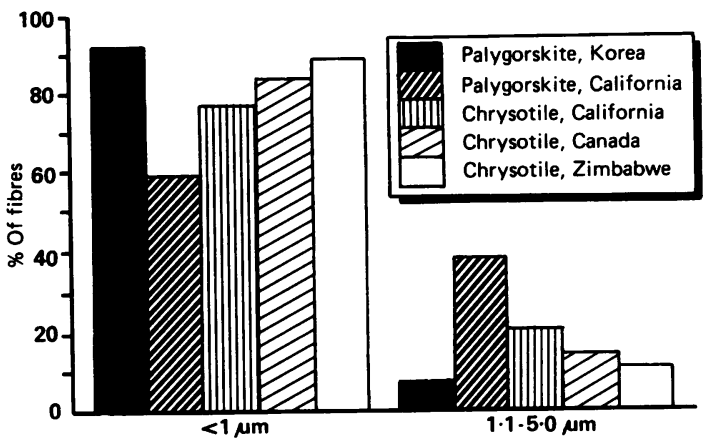

Figure 8 Comparison of the lengths of two palygorskite and three chrysotile specimens. The longest and the shortest palygorskite specimens were selected for comparison. The percentage of fibres $<1 \mu \mathrm{m}$ and $1 \cdot 1-5 \cdot 0 \mu \mathrm{m}$ in length are shown. The vertical scale is given as per cent of total population within that size category.

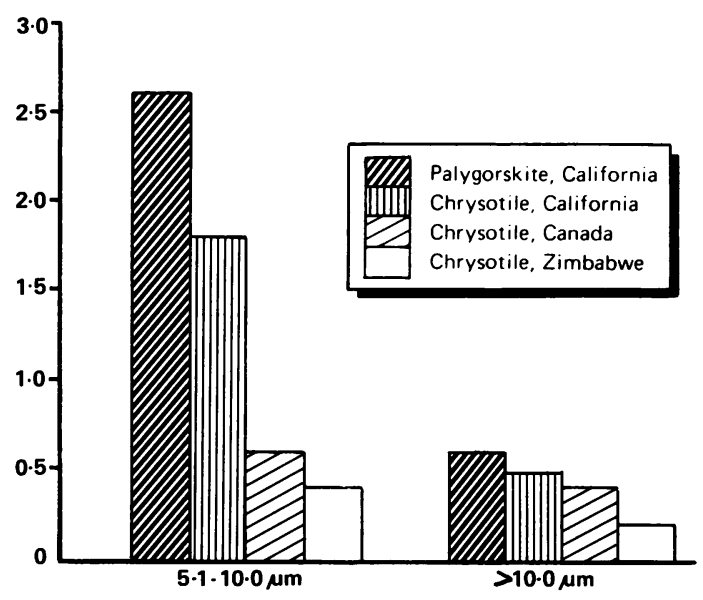

Figure 9 Comparison of the lengths of fibres $5.1 \mu \mathrm{m}$ and $>10.0 \mu \mathrm{m}$ in one palygorskite and three chrysotile specimens (no fibres in this range were found for the shortest palygorskite specimen (from Korea)).

fibrous synthetic erionite specimen produced a $5 \%$ mortality from mesothelioma. Induction of mesothelioma using inhalation as the route of administration has been criticised for producing too few mesotheliomas even with a potent mesothelial carcinogen like crocidolite. ${ }^{33} \mathrm{~A}$ recent intrapleural inoculation study of erionite has reported it to be $>200$-fold more oncogenic on a mass basis than crocidolite; again the size distributions of each specimen were similar. ${ }^{34}$

Epidemiological studies of populations exposed to these two minerals support the results of the animal studies. Environmental exposure to erionite can cause a $40 \%$ mesothelioma mortality whereas even after heavy occupational exposure to amphiboles, such as that experienced by United States insulation workers, a mesothelioma mortality of $>10 \%$ has never been reported. ${ }^{35}{ }^{36}$ Morphology alone is an uncertain prognosticator of a fibre's potential for biological potential, much less its hazard to human health.

Single mineral types may have both naturally occurring and industrially produced differences in physicochemical properties. Industrially used palygorskites are manipulated to alter their surface properties. ${ }^{87}$ All the health hazard studies to date have been on naturally occurring specimens, none of which have been reported to be industrially altered. Heating is commonly used in one such modification process. The thermal treatment changes the continuous scan $x$ ray diffraction characteristics. The diagnostic $10.5 \AA$ peak when heated decreases in intensity and disappears at $600^{\circ} .{ }^{10} 37$

These types of variation indicate that the mineral's health hazard evaluation cannot be based on evidence derived from a single source. Experimental carcinogenesis studies of palygorskite specimens from different geological origins have shown a range of activities. The implantation method of Stanton produced few tumours using two samples from Attapulgus, Georgia (table 5). ${ }^{24}$ The size distributions of the two Attapulgus specimens were similar to the three reported here (tables 3 and 5). Among four specimens in which carcinogenicities were evaluated by intraperitoneal injection, an Attapulgus specimen again produced few tumours as did a specimen from Mormoiron whereas a specimen from Torrejon induced a significant number of tumours (table 5). ${ }^{31} \mathrm{~A}$ different sample from the same Torrejon geological locale, produced $35 \%$ tumours by intrapleural injection and a different specimen from Mormoiron again yielded none (table 5). ${ }^{38}{ }^{39}$ Specimens from Lebrija produced very few tumours by intraperitoneal or intrapleural injection, although a few were produced by inhalation. The size distributions of the chrysotile specimens were comparable with the three specimens from Attapulgus, Georgia but their carcinogenic activities were very different (tables 3 and 6 ).

Unfortunately, sufficient amounts of the Torrejon palygorskite were not available for an inhalation experiment. A different palygorskite specimen from Leicester, United Kingdom was evaluated by inhalation and produced three mesotheliomas including one of the peritoneal form in $\mathbf{4 0}$ rats. Crocidolite used in that experiment as a positive control produced no mesotheliomas in a similar number of rats. Also, the Leicester specimen on a mass basis produced more mesotheliomas by intrapleural injection than did crocidolite (table 5$)^{39}$

The International Agency for Research on Cancer (IARC) currently classifies the animal experimental data for palygorskite as limited. ${ }^{37}$ The data in our study indicate that the IARC classification would be 
Table 5 Characteristics of palygorskite fibres used in animal experimental models

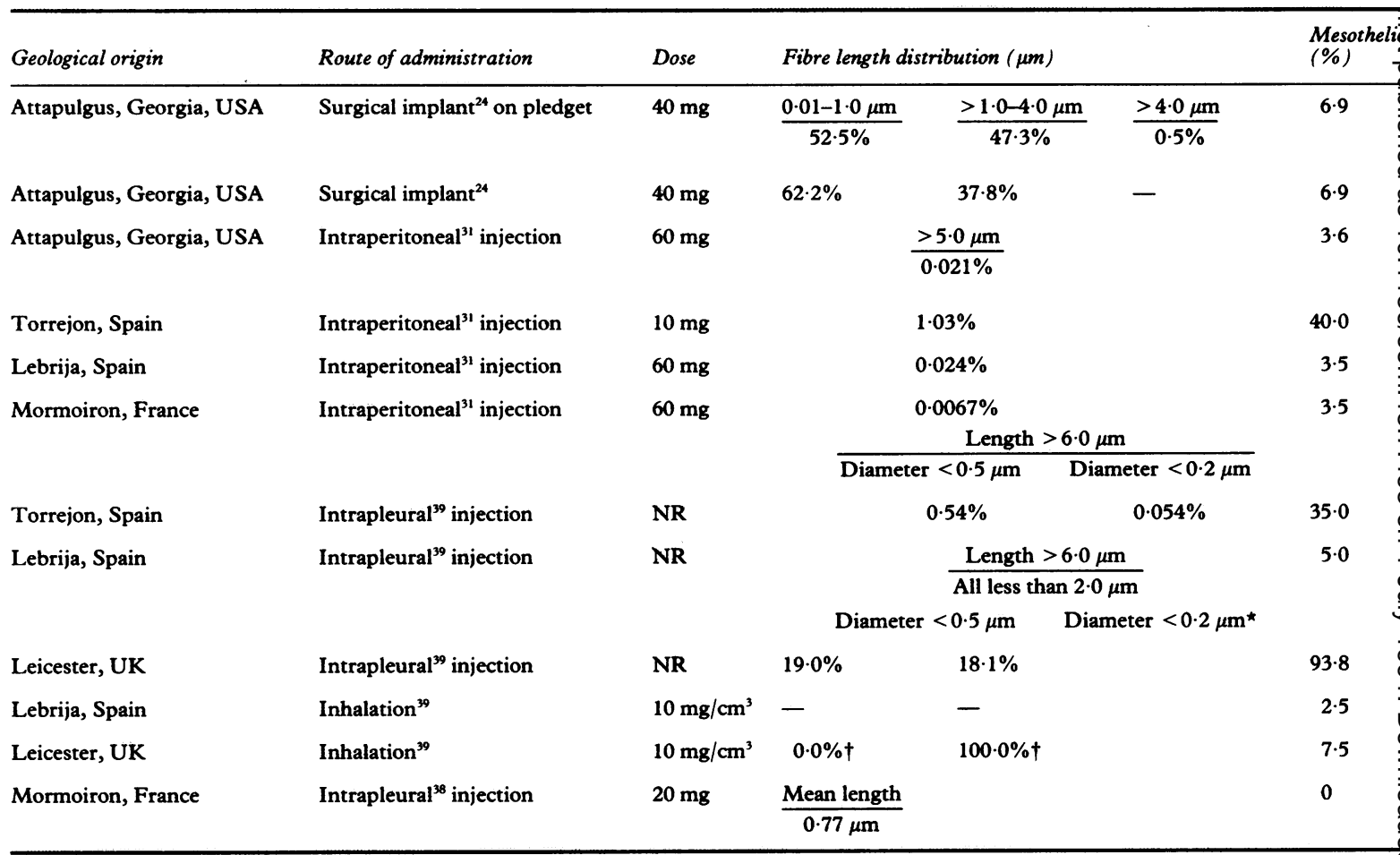

*AM $>6 \mu \mathrm{m}$ in length.

†Recovered from lung tissue.

NR $=$ Not reported.

Table 6 Characteristics of chrysotile fibres used in animal experimental models

\begin{tabular}{|c|c|c|c|c|}
\hline Geological origin & Route of administration & Dose & $\begin{array}{l}\text { Fibre length } \\
\text { distribution }\end{array}$ & Mesotheliomas (\%) \\
\hline $\begin{array}{l}\text { Canada } \\
\text { Canada } \\
\text { Zimbabwe } \\
\text { California }\end{array}$ & $\begin{array}{l}\text { Intraperitoneal }^{3} \\
\text { Intrapleural }^{3} \\
\text { Intraperitoneal }^{3} \\
\text { Intraperitoneal }^{3}\end{array}$ & $\begin{array}{l}25 \mathrm{mg} \\
25 \mathrm{mg} \\
25 \mathrm{mg} \\
25 \mathrm{mg}\end{array}$ & $\begin{array}{l}\text { NR } \\
\text { NR } \\
\text { NR } \\
\text { NR }\end{array}$ & $\begin{array}{l}80 \\
65 \\
82 \cdot 5 \\
72 \cdot 5\end{array}$ \\
\hline
\end{tabular}

NR = Not reported.

better served if some notation of range of activities were presented. Further, animal experimental studies may consistently show variable carcinogenicity for palygorskite, depending on its geological origin. Mineral name and morphology alone are insufficient to define a mineral's carcinogenic properties. The fibre size distribution and unusual surface adsorption characteristics of certain palygorskite specimens, along with the mineral's anticipated stability in vivo, are strong indicators suggesting that certain specimens will present a health hazard when inhaled.
This study was made possible by the support of the Societé Nationale de L'Amiante and the Asbestos Institute of Canada. R P Nolan wishes to acknowledge support as a fellow of the Stony Wold-Herbert Fund, New York, New York.

1 Bignon J, Sébastien P, Gaudichet A, Jaurand MC. Biological effects of attapulgite. In: Wagner JC, ed. Biological effects of mineral fiber. Vol 1. Lyon: International Agency for Research on Cancer, 1980:163-81. (Sci publ No 30.)

2 Yeager $H$, Russo $D$, Yanez $M$, et al. Cytotoxicity of a short-fiber chrysotile asbestos for human alveolar macrophages: Preliminary observations. Environ Res 1983;30:224-32. 
3 Maltoni C, Minardi F. Recent results of carcinogenicity bioassays of fibres and other particulate materials. In: Bignon J, Peto J, Saracci R, eds. Non-occupational exposure to mineral fibres. Lyon: International Agency for Research on Cancer, 1989:46-53. (Sci publ No 90.)

4 Nolan RP, Langer AM, Herson GB. Membranolytic activity and morphological characterization of palygorskite and sepiolite. In: Mossman BT, Begin R, eds. Mineral dusts on cells. Berlin: Springer-Verlag, 1989:37-48.

5 Ovcharenko FD, ed. The colloid chemistry of palygorskite. New York: Daniel Davey 1964. (English translation.)

6 Haden WL, Schwint IA. Attapulgite: Its properties and applications. Industrial Engineering Chemistry 1967;59:59-69.

7 Skinner HC, Ross M, Frondel C. Asbestos and other fibrous minerals. New York: Oxford University Press, 1988:204.

8 Solomon DH, Hawthorne DG. Chemistry of pigments and fillers. New York: John Wiley \& Sons, 1983:309.

9 Zoltai T, Stout JH. Mineralogy: Concepts and principles. Minneapolis: Burgess Publ Co, 1984.

10 Hayashi $H$, Otsuka R, Imai N. Infrared study of sepiolite and palygorskite on heating. American Minerologist 1969;53: 1613-24.

11 Serna C, VanScoyoc GE, Ahlrichs JL. Hydroxyl groups and water in palygorskite. American Minerology 1977;62:784-92.

12 Nolan RP, Langer AM, Harington JS, Oster G, Selikoff IJ. Quartz hemolysis as related to its surface functionalities. Environ Res 1981;26:503-20.

13 Bradley WF. The structure scheme of attapulgite. American Minerology 1940;25:405-10.

$14 \mathrm{MacNab}$ G, Harington JS. Hemolytic activity of asbestos and other mineral dusts. Nature 1967;214:522-3.

15 Schnitzer RJ, Pundsack FL. Asbestos hemolysis. Environ Res 1970;3:1-13.

16 Schnitzer RJ. Modification of biological surface activity of particles. Environ Health Perspect 1974;9:261-6.

17 Langer AM, Wolff MS, Rohl AN, Selikoff IJ. Variation of properties of chrysotile asbestos subjected to prolonged milling. J Toxicol Environ Health 1978;4:173-88.

18 Jaurand MC, Magne L, Bignon J. Inhibition by phospholipids of haemolytic action of asbestos. Br J Ind Med 1979;36:113-6.

19 Jaurand MC, Baillif R, Thomassin JH, Magne L, Touray JC. $\mathrm{X}$-ray photoelectron spectroscopy and chemical study of adsorption of biological molecules on chrysotile asbestos surface. Journal of Colloid and Interfacial Science 1983;95:1-9.

20 Pederiset M, Saint Etienne L, Bignon J, Jaurand MC. Interaction of attapulgite (fibrous clay) with human red blood cells. Toxicol Lett 1989;47:303-7.

21 Nolan RP, Langer AM. Quantitative aspects of fibre morphology. In: Proceedings of fibres in friction material symposium. Quebec: The Asbestos Institute, 1987:75-97.

22 Saffiotti U, Stinson F. Lung Cancer Induction by Crystalline Silica: Relationships to granulomatous reactions and host factors. J Environ Sci Health 1988;C6(2):197-222.

23 Nolan RP, Langer AM, Eskenazi RA, Herson GB. Membranolytic activities of quartz standards. Toxicology In Vitro 1987;1:239-45.

24 Stanton MF, Layard M, Tegeris $A$, et al. Relation of particle dimension to carcinogenicity in amphibole asbestoses and other fibrous minerals. J Natl Cancer Inst 1981;67:965-75.

25 Pott F, Huth F, Friedrichs KH. Tumorigenic effect of fibrous dusts in experimental animals. Environ Health Perspect 1974; 9:343-5.

26 Davis JMG. Mineral fibre carcinogenesis: Experimental data relating to the importance of fibre type, size, deposition, dissolution and migration. In: Bignon J, Peto J, Saracci R, eds. Non-occupational exposure to mineral fibres. Lyon: International Agency for Research on Cancer, 1989:33-45. (Sci publ No 90 .)

27 Wagner JC, Skidmore JW, Hill RJ, Griffiths DM. Erionite exposure and mesothelioma in rats. Br J Cancer 1985;51: $727-30$.

28 Timbrell V. Review of the significance of fibre size in fibre-related lung disease: a centrifuge cell for preparing accurate microscope-evaluation specimens from slurries used in sonication studies. Ann Occup Hyg 1989;33:483-505.

29 Rödelsperger K, Bruckel B, Manke J, Woitowitz HJ, Pott F. Potential health risks from the use of fibrous mineral absorption granulates. $\mathrm{Br} J$ Ind Med 1987;44:337-43.

30 Rödelsperger K, Bruckel B, Woitowitz HJ, Pott F, Strubel G. The proportion of long fibres in attapulgite and sepiolite containing adsorption granules. Cincinnati: US Department of Health and Human Services, 1990. (DHHS (NIOSH) publ No 90-108, pt 1, 554-558.)

31 Pott F, Ziem U, Reiffer FJ, Huth F, Ernst H, Mohr U. Carcinogenicity studies on fibers, metal compounds and some other dusts in rats. Exp Pathol 1987;32:129-52.

32 Okada S, Hamazaki S, Toyokuni S, Midorikawa O. Induction of mesothelioma by intraperitoneal injection of ferric saccharate in male Wistar rats. $\mathrm{Br} J$ Cancer 1989;60:708-11.

33 Pott F, Bellmann B, Muhle $\mathrm{H}$, et al. Intrapleural injection studies for the evaluation of the carcinogenicity of fibrous phyllosilicates. In: Bignon J, ed. Health related effects of phyllosilicates NATO ASI Services. Berlin: Springer-Verlag, 1990:319-29.

34 Langer AM, Nolan RP. Fiber type and mesothelioma risk. In: Symposium on health aspects of exposure to asbestos in buildings. Harvard: Harvard University, Energy and Environmental Policy Center 1989:91-140.

35 Hill RJ, Edwards RE, Carthew P. Early changes in the pleural mesothelioma following intrapleural inoculation of the mineral fibre erionite and the subsequent development of mesothelioma. J Exp Pathol 1990;71:105-18.

36 International Agency for Research on Cancer. Monographs on the evaluation of the carcinogenic risks of chemicals to humans. Silica and some silicates. Lyon: International Agency for Research on Cancer, 1987:225-39. (Sci publ No 42.)

37 International Agency for Research on Cancer. Monographs on the evaluation of the carcinogenic risks of chemicals to humans. Silica and some silicates. Lyon: International Agency for Research on Cancer, 1987:159-70. (Sci publ No 42.)

38 Jaurand MC, Fleury J, Monchaux G, Nebut M, Bignon J. Pleural carcinogenic potency of mineral fibers (asbestos, attapulgite) and their cytotoxicity on cultured cells. J Natl Cancer Inst 1987;79:797-804.

39 Wagner JC, Griffiths DM, Munday DE. Experimental studies with palygorskite dusts. $B r J$ Ind Med 1987;44:749-63.

Accepted 26 November 1990 